\title{
FAKTOR-FAKTOR PENENTU VOLATILITAS HARGA SAHAM SEKTOR PERUSAHAAN PROPERTI, REAL ESTATE DAN BUILDING CONSTRUCTION
}

\author{
Anisa Ferata Ayuning Putri \\ Program Studi Akuntansi Fakultas Ekonomi Universitas Islam Batik Surakarta \\ 1․ㅡisaferata12@gmail.com
}

\begin{abstract}
Abstrack : The purpose of this study is to examine the effect of Dividend Payment Ratio, Dividend Results, Productive Volatility, Estimated Assets, Leverage, Firm Size and Blockholders on Stock Price Volatility. In this study will use the report data of Financial Institution Companies from the Indonesia Stock Exchange (BEI) during the 2016-2018 period with a population of 201 companies using a purposive sampling method for a 3year sample of 36 companies. The data of this study were analyzed using multiple linear regression analysis. The results of the analysis found that Dividend Payment Ratios, Income Volatility, Assets, Company Size, Blockholdres are not in conflict with Stock Price Volatility While for the Result Dividend variable produced on Stock Price Volatility.
\end{abstract}

Keywords: Stock Price Volatility, Dividend Payout Ratio, Yield Dividend, Income Volatility, Asset Inventory, Firm Size, Blockholding

\section{PENDAHULUAN}

Pada sepanjang tahun 2018 Bursa Efek Indonesia mencatatkan saham yang masuk dalam kategori unusual market activity (UMA) dan tercatat ada 51 saham. Bahkan diantaranya terdapat 3 saham yang dilabeli saham UMA hingga lebih dari sekali yakni saham PT Arthavest Tbk (ARTA), PCAR (PT Prima Cakrawala Abadi Tbk) dan PT Transcoal Pacific Tbk (TCPI). Menanggapi kondisi ini, Reza Priyambada selaku Analis Senior CSA Research Institute berpendapat, sebenarnya saham yang masuk dalam kategori UMA belum tentu bermasalah, pergerakan sahamnya memang liar dengan volatilitas yang tinggi. Artinya investor masih bisa masuk dan keluar memanfaatkan volatilitas yang tinggi Tapi menurutnya saham UMA termasuk saham yang berisiko karena memang saham dengan volatilitas tinggi memiliki risiko yang tinggi pula. (https://amp.kontan.co.id)

Asosiasi Real Estate Indonesia atau REI merangkum data terkait usaha prooperti di indonesia, dan berdasarkan data tersebut di indonesia usaha properti mengalami kenaikan sebanyak 30 persen. Data tersebut memperlihatkan jika perputaran bisnis properti tersebut masih belum maksimal. Asosiasi REI memperhitungkan jika bisnis properti dapat terus mengalami peningkatan hingga tahun 2018. Pebisnis properti dapat memakai peluang ini untuk meningkatkan bisnis propertinya. Pada pameran RE Expo di Makasar tahun 2015, berpendapat bahwa perbandingan pertumbuhan bisnis properti cukup tinggi. Pameran tersebut membandingkan tingkat pertumbuhan bisnis properti tahun ini dan pada tahun 2014, tercatat untuk tahun 2014 bisnis properti hanya meningkat sekitar 15 hingga 20 persen saja dan untuk tahun 2015 investasi properti kembali dia angka normal. (http://direktoritraining.com)

\section{Tujuan Penulisan}

1. Untuk mengidentifikasi dan menganalisis pengaruh Deviden Payout Ratio (DPR) terhada Volatilitas Harga Saham (VHS) pada Perusahaan Properti, Real Estate dan Building Construction Tahun 2016-2018

2. Untuk mengidentifikasi dan menganalisis pengaruh Deviden Yield (DY) terhadap Volatilitas Harga Saham (VHS) pada Perusahaan Properti, Real Estate dan Building Construction Tahun 2016-2018

3. Untuk mengidentifikasi dan menganalisis pengaruh EV terhadap Volatilitas Harga Saham (VHS) pada Perusahaan Properti, Real Estate dan Building Construction Tahun 2016 2018 
4. Untuk mengidentifikasi dan menganalisis pengaruh Pertumbuhan Asset (PA) terhadap Volatilitas Harga Saham (VHS) pada Perusahaan Properti, Real Estate dan Building Construction Tahun 2016 - 2018

5. Untuk mengidentifikasi dan menganalisis pengaruh Leverage (LEV) terhadap Volatilitas Harga Saham (VHS) pada Perusahaan Properti, Real Estate dan Building Construction Tahun 2016 - 2018

6. Untuk mengidentifikasi dan menganalisis pengaruh Ukura erusahaan (UP) terhadap Volatilitas Harga Saham (VHS) pada Perusahaan Properti, Real Estate dan Building Construction Tahun 2016 - 2018

7. Untuk mengidentifikasi dan menganalisis pengaruh Blockholders (BHD) terhadap Volatilitas Harga Saham (VHS) pada Perusahaan Properti, Real Estate dan Building Construction Tahun 2016 $-2018$

\section{Kerangka Kerja Teoritis}

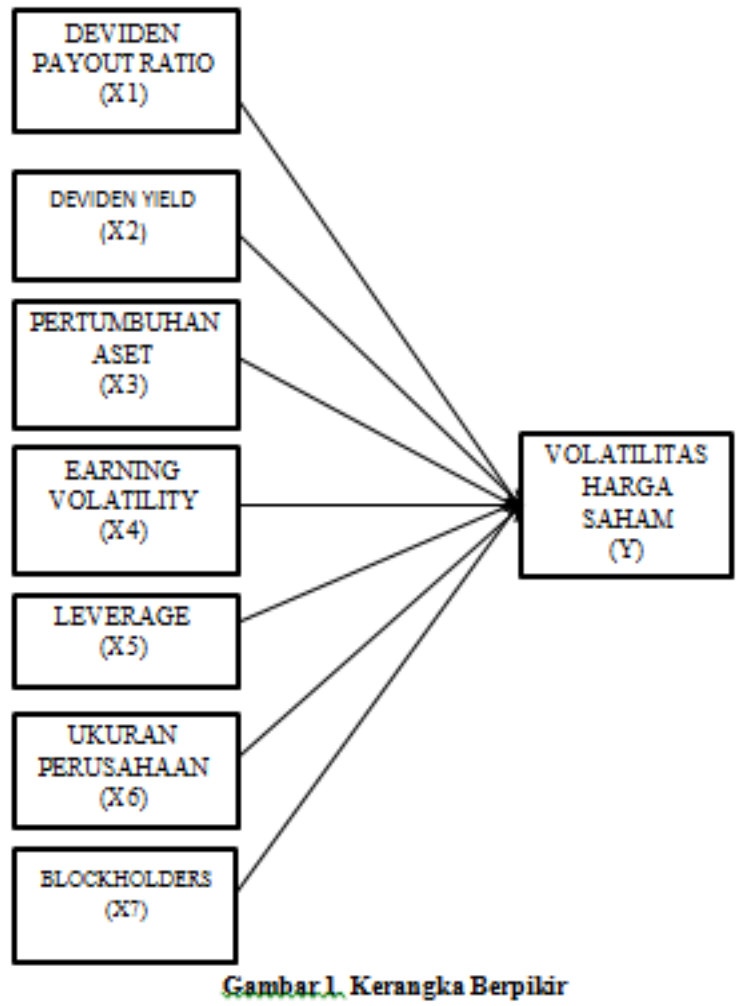

\section{Penjelasan :}

1. Volatilitas Harga Saham (VHS)
Volatilitas merupakan pengukuran dasar terhadap resiko yang berhubungan dengan instrumen pasar keuangan atau bisa juga di artikan sebagai jarak naik turunnya perubahan harga saham yang menujukan fluktuasi (ketidak tetapan) pasar pasa saat periode tertentu.

\section{Pengaruh DPR terhadap VHS}

DPR berfungsi sebagai pengukur berapa banyak jumlah yang akan diberikan untuk para shareholder atas laba berupa deviden. Pemberitahuan pemberian dividen untuk sharehoder memiliki informasi yang dapat berakibat pada reaksi harga saham. Apabila dividend yang diserahkan untuk shareholder semakin tinggi maka investor akan menahan saham yang dimilikinya maka yang akan terjadi adalah terjadi selisih penjual serta pembeli saham dapat menurun sehingga membuat harga saham cenderung stabil.

3. Pengaruh DY terhadap VHS

Harga saham atas suatu perusahaan beserta dividend yield tinggi maka akan mendapatkan balasan yang lamban pada perubahan tingkat diskon dikarenakan dividend yield yang meningkat akan melibatkan terjadinya aliran kas jangka pendek.

4. Pengaruh PA terhadap VHS

apabila pertumbuhan asset naik maka para investor akan lebih percaya diri untuk menginvestasikan uangnya. Oleh karena itu tingkat volatilitas lebih rendah.

5. Pengaruh EA terhadap VHS

apabila laba terjadi kenaikan dan penurunan yang kurang jelas, mengakibatkan harga saham yang kurang kuat. Hal itulah yang menyebabkan perubahan atau volatilitas harga saham kurang bagus ataupun cenderung tinggi.

6. Pengaruh Leverage (LEV) terhadap VHS

Apabila perusahaan memiliki banyak liabilitas yang belum terbayarkan maka akan membuat para investor menarik sahamnya dikarenakan perusahaan belum bisa memberikan jaminan kuat, sehingga kepercayaan para investor menurun. Sehingga berakibat pada volatilitas yang meninggi.

\section{Pengaruh UK terhadap VHS}

Ukuran perusahaan atau firm size bisa menyampaikan data untuk anggota penyelenggara pasar modal yang bisa membuktikan jika perusahaan bisa mengelola kegiatan usahanya dengan baik sehingga dapat berpengaruh terhadap keputusan para investor yang dapat dilihat dari perubahan harga saham perusahaan. Sehingga keadaan tersebiut bisa menghasilkan pengaruh pada perubahan harga 
saham di pasar modal. Ukuran perusahaan bisa bertambah saat harga saham meningkat.

8. Pengaruh Blockholders terhadap VHS blockholders memiliki pengaruh pada langkah investor minoritas pada saat membuat rencana perdagangan terkait investasinya, yang tercermin pada volatility atau fluktuasi harga saham harian .

\section{Pengembangan Hipotesis}

Berikut dugaan sementara berdasarkan penelitian sebelumnya yang akan diuji kembali, maka Hipoteris dari penelitian ini adalah :

\section{DPR}

Menurut penelitian Novius (2017) Uji Hipotesis secara simultan berpendapat bahwa bahwa DPR memiliki pengaruh pada VHS. Memiliki kesamaan dengan riset Priyana \& RM (2017) kesanggupan perusahaan menaikkan keuntungan disertai dengan besarnya dividen yang akan dibagikan dapat membawa dampak kenaikan harga saham diakibatkan dikarenakan para investor terbujuk untuk menyuntikkan modal pada perusahaan yang mempunyai kesanggupan dalam mendatangkan keuntungan.

\section{H1 : $D P R$ berpengaruh terhadap VHS}

2. DY

Berdasarkan penelitian oleh Selpiana \& Badjra (2018) menyatakan kebijakan dividen yang diproksikan dengan DY berpengaruh pada VHS. Sesuai dengan penelitian oleh Andiani \& Gayatri (2018) peningkatan DY bisa memberikan pengaruh terhadap tinggi rendahnya keinginan investor dalama berinvestasi di pasar modal sehingga berdampak bagi pemegang saham.

H2 : DY berpengaruh terhadap VHS

3. EA

Menurut penelitian Zainudin, Mahdaz, \& Yet (2017) Hasil penelitian mereka menyatakan jika ada EV berpengaruh terhadap VHS. Memiliki kesamaan dengan riset yang dilalukan Ahmad, Alrjoub, \& Alrabba (2018) bependapat jika Earning Volatility memiliki pengaruh yang terhadap VHS. Investor berfungsi sebagai pengukur tingkat earning volatility untuk memperkirakan harga saham di pasar modal.

H3 : Earning Volatility Berpengaruh terhadap Volatilitas Harga Saham

4. PA

Chaudry, Iqbal, \& Butt ( 2015 ) berpendapat PA berpengaruh terhadap VHS. apabila perrtumbuan asset naik maka para investor akan lebih percaya diri untuk menginvestasikan uangnya

\section{H4 : PA berpengaruh terhadap VHS}

5. Leverage (LEV)

Menurut penelitian Ahmad, Alrjoub, \&

Alrabba (2018) Leverage memiliki pengaruh positif dengan VHS. Temuan ini menyiratkan jika leverage meninggi, maka semakin tinggi juga VHS

H5 : Lev berpengaruh terhadap VHS

6. UP

Menurut penelitian Anastassia \& Firnanti, (2014) UP berpengaruh terhadap VHS. Sesuai dengan penelitian oleh Hashemijoo, Ardekani, \& Younesi (2012) peningkatan UP maka diversifikasi aktivitasnya juga semakin tinggi sehingga perusahaan dengan peningkatan yang tinggi memiliki informasi publik lebih banyak sehingga bisa menekan volatilitas harga saham.

\section{H6 : UP berpengaruh terhadap VHS}

7. Blockholders

Menurut penelitian Anom \& Safii,(2017) bahwa terdapat pengaruh dari kepemilikan blockholders terhadap VHS. Hasil tersebut menyampaikan rekaan jika selisih banyaknya kepemilikan saham antara Blockholders dan investor minoritas memicu perbedaan strategi perdagangan diantara kedua tipe investor tersebut, Sehingga keberadaan blockholders dapat berpengaruh terhadap keputusan investor minoritas dalam menyusun strategi perdagangan terkait investasinya, yang tercermin pada volatility atau fluktuasi harga saham.

H7 : Blockholders berpengaruh terhadap VHS.

\section{TINJAUAN LITERATUR}

\section{Penelitian Sebelumnya}

Penelitian oleh Nasir, Diana, \& Mawardi (2018) dengan judul Analisis FaktorFaktor Yang Mempengaruhi Volatilitas Harga Saham. Dengan hasil UP memiliki berpengaruh negatif signifikan terhadap VHS, DPR tidak berpengaruh signifikan terhadap VHS

Penelitian Oleh Azura, Sofia, \& Nurhasanah (2018) berjudul Pengaruh 
Kebijakan Deviden, , EV, Leverage, dan UP terhadap VHS Perusahaan LQ45. Hasil penelitian ini menunjukan DPR berpengaruh terhadap VHS, DY berpengaruh terhadap VHS, volume perdagangan tidak berpengaruh terhadap, Leverage tidak berpengaruh terhadap VHS, EV tidak berpengaruh terhadap VHS, firm sizeberpengaruh terhadap volatilitas harga saham.

Penelitian Oleh Neelanjana \& Hassan (2019) berjudul Dampak Kebijakan Dividen pada Volatilitas Saham Harga perusahaan Manufaktur di Malaysia. Hasil penelitian ini menunjukan Dividen Payout tidak berdampak terhadap VHS, Dividen Yield tidak berdampak terhadap VHS, Earning Volatility tidak berdampak terhadap VHS, ukuran perusahaan berdampak terhadap VHS.

\section{Tinjauan Teori}

a) Signaling Theory

Brigham \& Houston (2014) Teori Sinyal atau Signalling Theory merupakan penjelasan terkait hal hal yang akurat yang dibutuhkan shareholder sebagai dasar untuk mengamati dan kaji pasar dan harga saham yang di anggap sebagai "sinyal" yang memutuskan dalam investasi. Saat harga sama terus menerus turun akan berakibat pada yang minat investor untuk membeli saham di Index Indonesia menurun.

b) Volatilitas Harga Saham (VHS)

VHS merupaka sebagian dari tolak ukur untuk melakukan sebuah inveatasi, ukuran tersebut menjelaskan resiko pergerakan harga dari sekuritas. Pengukuran dari VHS menurut Hashemijoo, Ardekani, \& Younesi (2012) yaitu menggunakan Jarak tahunan dari harga saham paling tinggi dengan peling renddah per bulan kemusian dibagi rata rata harga saham perusahaan tertinggi dan terendah. Berikut rumusnya :

$$
\text { SPV }=\frac{\text { Hit-Lit }}{[\text { Hit }+ \text { Lit }]: 2}
$$

Keterangan :

SPV : Volatilitas Harga Saham

Hit : Harga Saham Tertinggi Perusahaan i pada Periote t

Lit : Harga Saham Terendah Perusahaan i pada Periote t

c) Deviden Payout Ratio
Sartono (2008) mengatakan bahwa Dividend Payout Ratio dapat diartikan dengan presentase laba yang dibayar berbentuk deviden untuk pemegang saham. DPR merupakan tingkat pembagian lana perusahaan terhadap pemegang saham atau seorang investor. Berikut perhitungannya Menurut Hashemijoo, Ardekani, \& Younesi (2012).

Dividend Payout Ratio $=\frac{\text { Dividen }}{\text { Laba Bersih Setelah Pajak }}$

d) Deviden Yield

(2013) Denurut Khurniaji \& Raharja, mengenai berapa besar laba yang akan didapatkan oleh investor dari investasi mereka terhadap perusahaan, ditandai dengan Yield yang diukur menggunakan cara membagi antar dividend per share (DPS) dan harga saham per lembar.

\section{Dividend Yield $=\frac{\text { Dividend Per Share }}{\text { harga saham per lembar }}$}

e) Earning Volatility (EV)

Theresia dan Arilyn (2015) berpendapat bahwa earning volatility merupakan definisi keuntungan fluktuatif atas perusahaan yang menjelaskan akibat dari aktivitas perusahaan. Hal ini dapat berpengaruh terhadap ketentuan investor terkait akibat yang terjadi pada perusahaan. Ardekani, \& Younesi, (2012) menyatakan jika resiko pasar yang akan dihadapi oleh perusahaa bisa berpengaruh baik terhadap VHS ataupun dividen policy. Berikut perhitunganya

\section{Eaming Volatility $=$ Laba Setelah Pajak Total Aset}

f) Pertumbuhan Aset (PA)

Tambunan (2007) Berpendapat bahwa Pertumbuhan Aset merupakan kenaikan penghasilan dan keuntungan di atas rata-rata perusahaan untuk melakukan kegiatan perusahaan. Perusahaan saat mengalami masa pertumbuhan cenderung menahan laba perusahaan untuk melakukan investasi di waktu yang akan datang sehingga meningkatkan resiko. Perhitungan menurut Ardiyansyah \& Isbanah,(2017) yaitu menggunakan jumlah aset tahun tersebut di kurang dengan tahun 
sebelumnya lalu di bagi dengan total aset tahun lalu

Pertumbuhan Aset $=$ Total Aset $\mathrm{t}+$ Total Aset $\mathrm{t}-1$ Total Aset t-1

g) Leverage (LEV)

Menurut Priyana \& RM (2017) Leverage merupakan pemakaian aset dan sumber dana biaya tetap perusahaan ydengan tujuan menaikan keuntungan pemegang saham. Hashemijoo, Ardekani, \& Younesi,(2012) berpendapat bahwa risiko operasi, tingkat liabilitas perusahaan bisa memiliki pengaruh yang negatif terhadap volatilitas harga saham

\section{Debt to Equity Ratio $=\frac{\text { Total Hutang }}{\text { Total Ekuitas }}$}

h) Ukuran Perusahaan (UP)

Tambunan (2007) berpendapat bahwa Ukuran Perusahaan dapat didefinisikan sebagai pengukuran kinerja operasional dari perusahaan dengan menunjukan bagaimana manajemen perusahaan menjalan kan perusahaan dengan baik. Berikut rumus Ukuran Perusahaan menurut Ardiyansyah \& Isbanah, (2017)

\section{Ukuran Perusahaan $=$ LnTotalAsset}

i) Blockholders

Shleifer \& Vinshny (1997) menyatakan Blockholders atau bisa disebut juga Kepemilikan Besar merupaksan suatu entitas yang memiliki lebih dari 5\% dari jumlah saham suatu perusahaan. Entitas tersebut dapat terdiri dari karyawan, direktur, keluarga orang yang bekerja di perusahaan, institusi, individu atau orang yang tidak berkaitan dengan perusahaan. Perhitungan Blockholders menurut Wiliandri, (2011) sebagai berikut :

\section{Blockholders $=\quad$ Jumlah Saham Blockholders}

\section{METODE PENELITIAN}

Penelitain ini masuk dalam jenis penelitian Kuantitatif menggunakan data sekunder. karena mengacu pada perhitungan dan analisis data berupa angka. Penelitian ini bertujuan untuk mengetahui pengaruh hubungan antara dua variable atau lebih.

Perusahaan Properti, Real Estate dan Building Construction yang terdaftar di Bursa Efek Indonesia(BEI) merupakan populasi pada riset ini. Pengambilan sampel akan dilalukan menggunakan metode purposive sampling, sampel harus memenuhi kriteria tertentu sesuai dengan apa yang di kehendaki atau yang ditetapkan oleh peneliti sesuai dengan pertimbangan kriteria yang akan digunakan. Uji Asumsi Klasik dan Analisis Regresi Linier Berganda digunakan sebagai model analisis data pada penelitian ini 


\section{A. HASIL PENELITIAN}

Tabel 1. Kriteria Sampel

\begin{tabular}{clc} 
NO & \multicolumn{1}{c}{ Penentuan Sampel } & Total \\
\hline 1 & Perusahaan Properti, Real Estate dan Building Construction periode tahun & 201 \\
& 2016-2018 & $(66)$ \\
2 & Perusahaan terdaftar berturut turut di BEI selama periode tahun 2016-2018 & $(18)$ \\
3 & Mempublikasikan Annual Report di BEI selama periode tahun 2016-2018 & $(15)$ \\
4 & $\begin{array}{l}\text { Mengirimkan datanya lengkap sesuai dengan keterangan yang diperlukan oleh } \\
\text { variabel }\end{array}$ & $(60)$ \\
& $\begin{array}{l}\text { Perusahaan yang memnyerahkan dividen pada shareholders secara berturut } \\
\text { turut periode tahun 2016-2018 }\end{array}$ & $(6)$ \\
Jumlah sampel periode tahun 2016-2018 & 36 \\
\hline
\end{tabular}

Sumber Data : Data Sekunder diolah (2019)

Tabel 2.1 Hasil Uji Normalitas

\begin{tabular}{cccc}
\hline Variabel & Syarat & Sig. & Keterangan \\
\hline $\begin{array}{l}\text { Unstandardized } \\
\text { Residual }\end{array}$ & $>0,05$ & 0,2 & $\begin{array}{c}\text { Terdistribusi } \\
\text { Normal }\end{array}$ \\
\hline $\begin{array}{l}\text { Sumber : Data diolah } \\
\text { Tabel 2.1 nilai Sig terhitung }\end{array}$ & 0,200 . Syarat \\
nilai Sig $>0,05$ maka dinyatakan bahwa nilai residual \\
terdistribusi dengan normal.
\end{tabular}

$\underline{\text { Tabel 2.2 Hasil Uji Multikolinieritas }}$

\begin{tabular}{cccccc} 
Variabel & $\begin{array}{c}\text { Syarat } \\
\text { Tolerance }\end{array}$ & Tolerance & $\begin{array}{c}\text { Syarat } \\
\text { VIF }\end{array}$ & VIF & Keterangan \\
\hline DPR & $>0.10$ & 0,913 & $<10$ & 1.095 & $\begin{array}{c}\text { Tidak Terjadi } \\
\text { Multikolinieritas }\end{array}$ \\
\hline DY & $>0.10$ & 0,775 & $<10$ & 1.291 & $\begin{array}{c}\text { Tidak Terjadi } \\
\text { Multikolinieritas }\end{array}$ \\
\hline EV & $>0.10$ & 0,393 & $<10$ & 2.545 & $\begin{array}{c}\text { Tidak Terjadi } \\
\text { Multikolinieritas }\end{array}$ \\
\hline PA & $>0.10$ & 0,246 & $<10$ & 4.062 & $\begin{array}{c}\text { Tidak Terjadi } \\
\text { Multikolinieritas }\end{array}$ \\
\hline LEV & $>0.10$ & 0,573 & $<10$ & 1.745 & $\begin{array}{c}\text { Tidak Terjadi } \\
\text { Multikolinieritas }\end{array}$ \\
\hline UP & $>0.10$ & 0,496 & $<10$ & 2.015 & $\begin{array}{c}\text { Tidak Terjadi } \\
\text { Multikolinieritas }\end{array}$ \\
\hline BHD & $>0.10$ & 0,569 & $<10$ & 1.759 & $\begin{array}{c}\text { Tidak Terjadi } \\
\text { Multikolinieritas }\end{array}$ \\
\hline Sumber : Data diolah \\
Pada Tabel 2.2 & terhitung & $\begin{array}{c}\text { Tahwa nilai } \\
\text { bala }\end{array}$
\end{tabular}

Tolerance ketujuh variabel lebih dari 0,10 dan VIF kurang dari 10, maka dapat disimpulkan tidak terjadi multikolinieritas antar variabel.

Tabel 2.3 Hasil Uji Autokorelasi

\begin{tabular}{|c|c|c|c|c|}
\hline $\begin{array}{l}\text { Nilai } \\
\text { Durbin } \\
\text { Watson }\end{array}$ & 4-d U & 4-d L & Syarat & Keterangan \\
\hline 2.149 & 2,0215 & 2,9854 & $\begin{array}{c}4-\mathrm{d} U< \\
\mathrm{DW}<4-\mathrm{d} \\
\mathrm{L}\end{array}$ & $\begin{array}{l}\text { Tidak ada } \\
\text { kepastian }\end{array}$ \\
\hline
\end{tabular}

$2.149<2,9854)$ kesimpulannya tidak ada kepastian.

Tabel 2.4 Hasil Uji Heterokedastisitas

\begin{tabular}{lccc}
\hline Variabel & Syarat & Sig. & \multicolumn{1}{c}{ Keterangan } \\
\hline DPR & $>0,05$ & 0.718 & Tidak Terjadi Masalah Heterokedastisitas \\
DY & $>0,05$ & 0.114 & Tidak Terjadi Masalah Heterokedastisitas \\
EV & $>0,05$ & 0.565 & Tidak Terjadi Masalah Heterokedastisitas \\
PA & $>0,05$ & 0.814 & Tidak Terjadi Masalah Heterokedastisitas \\
LEV & $>0,05$ & 0.871 & Tidak Terjadi Masalah Heterokedastisitas \\
UP & $>0,05$ & 0.134 & Tidak Terjadi Masalah Heterokedastisitas \\
BHD & $>0,05$ & 0.848 & Tidak Terjadi Masalah Heterokedastisitas \\
Sumber: Data diolah
\end{tabular}

Dari output diatas dapat diketahui nilai sig ke 7 variabel lebih dari 0,05. Kesimpulannya tidak terjadi masalah heteroskedastisitas.

Tabel 3.1 Model Regresi

\begin{tabular}{lr}
\hline \multicolumn{1}{c}{ Model } & \multicolumn{1}{c}{ B } \\
\hline (Constant) & $-42303,722$ \\
DPR & 3,867 \\
DY & $-2,512$ \\
EV & 3,866 \\
PA & 2,249 \\
LEV & $-7,321$ \\
UP & 0,114 \\
BHD & 1,276
\end{tabular}

Sumber : Data diolah

Model regresi dari tabel di atas diperoleh sebagai berikut :

SPV $=-42303,722+3,867-2,512+3,866+2,249$ -

$7,321+0,114+1,276$

Tabel 3.2 Hasil Uji F

\begin{tabular}{|c|c|c|c|c|}
\hline $\begin{array}{c}\mathrm{F} \\
\text { hitung }\end{array}$ & $\begin{array}{l}\mathrm{F} \\
\text { tabel }\end{array}$ & Sig. & $\begin{array}{c}\text { Kriteria } \\
\text { Pengujian }\end{array}$ & Keterangan \\
\hline 2.399 & 2,388 & 0.049 & $\begin{array}{c}\text { F hitung }> \\
\text { F tabel }\end{array}$ & Ho Ditolak \\
\hline
\end{tabular}


Sumber : Data diolah

$\mathrm{F}$ tabel terhitung sebesar 2,388. F hitung $>\mathrm{F}$ tabel dan signifikansi $0.049<0.05$ maka Ho ditolak. Kesimpulannya Devidend Payout Ratio, Devidend Yield, Earning Volatility, Pertumbuhan Aset, Leverage, Ukuran Perusahaan dan Blockholders berpengaruh terhadap Volatilitas Harga Saham.

\section{Tabel 3.3 Uji T}

\begin{tabular}{cccccr}
\hline Hipotesis & $\begin{array}{c}\mathrm{T} \\
\text { hitung }\end{array}$ & $\begin{array}{c}\mathrm{T} \\
\text { tabel }\end{array}$ & Sig. & Syarat & Hasil \\
\hline $\mathrm{H}_{1}$ & -0.610 & 2,056 & 0.547 & $<0.05$ & Ditolak \\
$\mathrm{H}_{2}$ & 2.527 & 2,056 & 0.018 & $<0.05$ & Diterim; \\
$\mathrm{H}_{3}$ & -0.994 & 2,056 & 0.329 & $<0.05$ & Ditolak \\
$\mathrm{H}_{5}$ & 0.360 & 2,056 & 0.721 & $<0.05$ & Ditolak \\
$\mathrm{H}_{3}$ & 0.998 & 2,056 & 0.328 & $<0.05$ & Ditolak \\
$\mathrm{H}_{6}$ & -1.943 & 2,056 & 0.063 & $<0.05$ & Ditolak \\
$\mathrm{H}_{7}$ & 1.163 & 2,056 & 0.255 & $<0.05$ & Ditolak \\
\hline
\end{tabular}

Sumber: Data diolah

Tabel 3.3 hasil Uji Hipotesis yang pertama $\mathrm{H}_{2}$ (Dividend Yield) memiliki $\mathrm{T}$ hitung $>\mathrm{T}$ tabel dan sig 0,018<0,05 maka hipotesis nya diterima. Uji Hipotesis kedua yaitu $\begin{array}{llllll}\mathrm{H}_{1} & \mathrm{H}_{3} & \mathrm{H}_{4} & \mathrm{H}_{5} & \mathrm{H}_{6} & \mathrm{H}_{7}\end{array}$ (Dividen Payout Ratio,Earning Volatility, Pertumbuhan Aset, Leverage, Ukuran Perusahaan, Blockholders) dengan $\mathrm{T}$ hitung $<\mathrm{T}$ tabel dan sig $>0,05$ maka hipotesis nya ditolak.

Tabel 3.4 Hasil Uji Koefisien Determinasi

\begin{tabular}{cc}
\hline Adjusted R Square & Kesimpulan \\
\hline 0,329 & $\begin{array}{c}\text { Berpengaruh } \\
\text { Sebesar 32,9\% }\end{array}$ \\
\hline $\begin{array}{c}\text { Sumber : Data diolah } \\
\text { tabel } 3.4 \text { nilai }\end{array}$ & Adjusted R Square sebesar \\
0,329 yang berarti berpengaruh 32,9\%.
\end{tabular}

\section{Pembahasan}

\section{Pengaruh DPR Terhadap VHS.}

Hasil dari riset ini adalah Dividen Payout Ratio tidak berpengaruh terhadap VHS. Karen total besaran dividend yang diterima shareholders tinggi maka investor akan menahan saham yang dimilikinya maka yang akan terjadi adalah harga saham cenderung kuat sehingga tidak terjadi volatilitas dikarenakan selisih atau volatilitas antara jual dan beli saham akan berkurang sehingga.

\section{Pengaruh Dividend Yield Terhadap VHS}

Hasil riset ini adalah Dividen Yield berpengaruh terhadap VHS. Hal tersebut dikarenakan perkiraan keuntungan di waktu kedeapan meleset terlalu tinggi sehingga harga saham perusahaan bisa saja berubah ubah disebabkan oleh volatility stock price yang lebih tinggi.

\section{Pengaruh Earning Volatility Terhadap VHS}

Hasil dari penelitian menunjukan Earning Volatility tidak berpengaruh terhadap VHS. Karena kenaikan dan penurunan laba yang pasti maka harga saham stabil, sehingga tingkat VHS cenderung rendah.

\section{Pengaruh PA Terhadap VHS}

Hasil dari penelitian ini menunjukan Pertumbuhan Aset tidak berpengaruh terhadap VHS. Karena pertumbuhan asset naik maka para investor akan merasa memiliki jaminan untuk menginvestasikan uangnya. Oleh karena itu tingkat volatilitas lebih rendah.

\section{Pengaruh Leverage Terhadap VHS}

\begin{tabular}{lrr}
\multicolumn{2}{c}{ Hasil dari } & penelitian \\
menunjukan & ini \\
beverage & tidak \\
berpengaruh terhadap & VHS. Hal
\end{tabular} dikarenakan utang perusahaan yang sedikit tidak mempengaruhi para investor sehingga para invester menahan sahamnya dan membuat volatilitas rendah.

\section{Pengaruh UP Terhadap VHS}

Hasil dari penelitian ini menunjukan UP tidak berpengaruh terhadap VHS. Karena perusahaan bisa mengelola kegiatan bisnisnya dengan baik sehingga dapat berpengaruh keputusan para investor untuk menahan sahamnya sehingga volatilitas harga saham rendah

\section{Pengaruh Blockholders Terhadap VHS}

Hasil dari penelitian ini
menunjukan berpengaruh terhadap VHS. Kaerena Blockholders pada saat membuat rencana perdagangan terkait investasinya tidak memepengaruhi investor minoritas sehingga tidak berpengaruh juga terhadap VHS.

\section{KESIMPULAN, KETERBATASAN DAN SARAN}

Tujuan dari penelitian ini adalah untuk melihat Pengaruh Devidend Payout Ratio, Devidend Yield, Earning Volatility (EV), Pertumbuhan Aset (PA), Leverage (LEV), Ukuran Perusahhan (UP) dan Blockholders terhadap VHS pada Perusahaan Properti, Real Estate dan Building Construction Tahun 2016 - 2018. Populasi penelitian ini terdiri dari 201 perusahaan 
selama 3 tahun, metode Purposive Sampling digunakan untuk menyeseleksi populasi hingga diperolehlah total sampel 36 Perusahaan. Uji Regresi Linier Berganda digunakan pada Penelitian ini. Hasil keseluruhan penelitian yang telah dilakuka dapat disimpulkan bahwa hipotesis yang pertama yaitu DPR tidak berpengaruh terhadap VHS hal ini sejalan dengan penelitian oleh Rowena \& Hendra (2017). Hipotesis yang kedua yaitu DY berpengaruh terhadap VHS hal ini sejalan dengan penelitian oleh Novius (2017). Hipotesis yang ketiga yaitu Earning Volatility tidak berpengaruh terhadap VHS hal ini tida sejalan dengan penelitian oleh Rowena \& Hendra (2017) . Hipotesis yang keempat yaitu Pertumbuhan Aset tidak berpengaruh terhadap VHS hal ini sejalan dengan penelitian oleh Rowena \& Hendra (2017). Hipotesis yang kelima Leverage tidak berpengaruh terhadap VHS hal ini tidak sejalan dengan penelitian oleh Sutandijo (2019). Hipotesis yang keenam yaitu Ukuran Perusahaan tidak berpengaruh terhadap VHS hal ini sejalan dengan penelitian oleh Sutandijo (2019) dan Hipotesis yang terakhir yaitu Blockholders tidak berpengaruh terhadap VHS hal ini tidak sejalan dengan penelitian oleh Anom \& Safii (2017) yang menyatakan bahwa Blockholders berpengaruh terhadap VHS.

\section{Keterbatasan}

a) Variable independen yang digunakan hanya 7 variabel.

b) Periode penelitian terlalu singkat hanya dalam tiga tahun saja sehingga belum bisa melihat secara jelas Pengaruh Devidend Payout Ratio, Devidend Yield, Earning Volatility (EV), Pertumbuhan Aset (PA), Leverage (LEV), Ukuran Perusahaan (UK) dan Blockholders terhadap Volatilitas Harga Saham

c) Nilai adjusted $\mathrm{R}$ square hanya sebesar $32,9 \%$. yang artinya ada factor selain variabel dalam penelitian ini yang mempengaruhi volatilitas harga saham namun masih belum di uji dalam penelitian ini

\section{Saran}

a) Untuk peneliti selanjutnya dapat menambah periode penelitian sehingga data lebih jelas

b) Pada riset selanjutnya bisa memasukan variabel lainnya

\section{Daftar Pustaka}

Ahmad, M. A., Alrjoub, A. M., \& Alrabba, H. M. (2018). The Effect Of Diviidend Policy On Stock Price Volatiliity: Empiricall Evidence From Amman StockExchange. Academy of Accountiing And Financial Studies Journal Volume 22, Number 2.

Anastassia, \& Firnanti, F. (2014). Faktor Faktor Yang Mempengaruhi Volatilitas Harga Saham Pada Perusahaan Publik Non Keuangan. Jurnal Bisnis Dan Akuntansi Vol 16 No 2, 95-102.

Andiani, N. S., \& Gayatri. (2018). Pengaruh Volume Perdagangan Saham, Volatilitas Laba, Dividend Yield,Dan Ukuran Perusahaan Pada Volatilitas Harga Saham. E-Jurnal Akuntansi Universitas Udayana Vol.24.3, 2148-2175.

Anom, L., \& Safii, A. A. (2017). Pengaruh Keberadaan Blockholdersterhadap Volatilitas Harga Saham. Jurnal Eksekutif Volume 14, $320-331$.

Ardiyansyah, I., \& Isbanah, Y. (2017). Analisis Pengaruh Deviden, Pertumbuhan Aset, Ukuran Perusahaan, Dan Leverage Terhadap Volatilitas Harga Saham . Jurnal Riset Akuntansi Dan Keuangan, 5 (3), 1565-1574.

Azura, S. N., Sofia, M., \& Nurhasanah. (2018). Faktor -Faktor Yang Mempengaruhi Volatilitas Harga Saham Pada Perusahaan Manufaktur Yang Tercatat Di Bursa Efek Indonesia Tahun 2012-2016. 1 - 20.

Brigham, F. E., \& Houston, J. (2014). Dasar-Dasar Manajemen Keuangan : Assetials of Financial. Jakarta: Salemba Empat.

Chaudry, S. N., Iqbal, S., \& Butt, M. (2015). Dividend Policy, Stock Price Volatility \& Firm Size Moderation: Investigation Of Bird In Hand Theory In Pakistan. Research Journal Of Finance And Accountingvol.6, No.23, , 16 -19.

Ema, N. (2013). Pengaruh Per, Eps, Roa, Dan Der Terhadap Harga Saham Perusahaan SubSektor Industri Textile Yang Go Public Di Bursa Efek Indonesia (Bei) Tahun 20092011.

Hashemijoo, M., Ardekani, A. M., \& Younesi, N. (2012). The Impact Of Dividend Policy On Share Price Volatility In The Malaysian Stock Market. Journal of Business Studies Quarterly, Vol. 4, No. 1, 111-129.

Khurniaji, A. W., \& Raharja, S. (2013). Hubungan Kebijakan Dividen (Dividend Payout 
Volume 8, Nomor 2, Agustus 2020

Ratiodan Dividend Yield) Terhadap Volatilitas Harga Saham Di PerusahaanPerusahaan Yang Terdaftar Di Bursa Efek Indonesia. Diponegoro Journal Of Accounting Volume 2, Nomor 3, 1-10.

Nasir, J. L., Diana, N., \& Mawardi , C. M. ( 2018). Analisis Faktor-Faktor Yang Mempengaruhi Volatilitas Harga Saham. E-Jra Vol. 07 No. 09, 24 - 38.

Neelanjana, B. H., \& Hassan, H. H. (2019). The Impact Of Dividend Policy On The Volatility Of Share Price Of Manufacturing Companies In Malaysia Volume-7 Issue-5s. International Journal Of Recent Technology And Engineering (Ijrte), 2012 - 224.

Novius, A. (2017). Analisis Pengaruh Kebijakan Dividen (Dividend Payout Ratio Dan Dividend Yield) Terhadap Volatilitas Harga Saham. Jurnal Al-Iqtishad, Edisi 13 Volume I , 67-77.

Priyana , I. W., \& Rm , K. M. (2017). Pengaruh Volume Perdagangan Saham, Leverage, Dan Dividend Payout Ratio Pada Volatilitas Harga Saham. E-Jurnal Akuntansi Universitas Udayana Vol.20.1, 1-29.

Rowena, J., \& Hendra. (2017). Earning Volatility, Kebijakan Dividen, Dan Pertumbuhan Asset Berpengaruh Terhadap Volatilitas Harga Saham Pada Perusahaan Manufaktur Di Bei Periode 2013 - 2015. Jurnal Administrasi Kantor, Vol.5, No.2, , 231 - 242.

Sartono , A. (2008). Manajemen Keuangan Teori Dan Aplikasi, Edisi Empat. Yogyakarta : Bpfe.

Selpiana, K. R., \& Badjra, I. B. (2018). Pengaruh Kebijakan Dividen, Nilai Tukar, Leverage, Dan Firm Size Terhadap Volatilitas Harga Saham. E-Jurnal Manajemen Unud, Vol. 7, No. 3, 1682-1712.

Shleifer, A., \& Vinshny, R. (1997). A Survey Of Corporate Governance. Journal Of Finance 52(2), 737-83. .

Stice, E., Stice , J., \& Skousen, K. (2005). "Intermediate Accounting", 15th Edition. Cincinati Ohio: South-Western Publishing Co.

Sutandijo. (2019). Kebijakan Dividen Dan Volatilitas Harga Saham. Jurnal Ilmiah Akuntansi Universitas Pamulang Vol. 7, No. 1, 1-14.

Tambunan, A. P. (2007). Menilai Harga Wajar Saham. Jakarta: Pt. Elex Media Komputindo.
Warsono. (2002). Manajemen Keuangan Perusahaan Jilid I. Jakarta: Bayu Media.

Wiliandri, R. (2011). Pengaruhblockholder Ownership Danfirm Sizeterhadap Kebijakan Hutang Perusahaan. Jurnal Ekonomi Bisnis, Th. 16, No. 2, 95-102.

Zainudin, R., Mahdaz, N. S., \& Yet, C. H. (2017). Dividend Policy And Stock Pricevolatility Of Industrial Productsfirms In Malaysia. International Journal Of Emerging Markets Vol. 13 No. 1, 203-217.

Https://Amp.Kontan.Co.Id

Http://Direktoritraining.Com 
